\title{
The Factors that Determine the Capital Structure among Insurance Companies in Kosovo: Empirical Analysis
}

\author{
Albulena Shala \\ PhD Candidate, Asistence Accounting and Finance Department, University of Pristina, "Hasan \\ Prishtina", Republic of Kosovo, e-mail: albulena.shala@hotmail.com
}

Skender Ahmeti

Professor, PhD, Accounting and Finance Department, University of Pristina, "Hasan Prishtina", Republic of Kosovo, e-mail: skender.ahmeti@yahoo.com;

Vlora Berisha

PhD Candidate, Asistence Accounting and Finance Department, University of Peja, "Haxhi Zeka", Republic of Kosovo, Republic of Kosovo, email: vlorab_402@hotmail.com,

Edona Perjuci

PhD Candidate, Asistence Accounting and Finance Department, University of Pristina, "Hasan Prishtina", Republic of Kosovo, e-mail: edonaperjuci@hotmail.com.

Doi:10.5901/ajis.2014.v3n2p43

\section{Abstract}

This research has aimed to analyze the determinants of capital structure among insurance companies in Kosovo, based on a data retrieved from 11 insurance companies during the period 2009-2012. For this purpose, the debt ratio is taken as a dependant variable whereas company size, growth, life, fixed assets and liquidity ratio were taken as independent variables. The result of RE model shows that these variables are in positive relationship with the debt ratio. On the other hand, the company size, the fixed assets ratio, liquidity ratio, company life and growth had considerable effects on debt equation. Based on the research results, the insurance companies should have a high consideration for asset increase because the size of company is an important factor that has a positive effect on debt/equity ratio.

Keywords: Debt ratio, Insurance companies in Kosova, Capital structure.

\section{Introduction}

The insurance companies are businesses that transfer the risk in exchange of the premium obtained from the insured party. It is possible that the amount collected as a premium from insurance policies is less than the total sum payable for insurance claims. If this happens, the insurer is expected to reimburse the claims from the equity of the insurance company. The owners (or investors) of insurance companies are concerned with the return and security of their investments. The concern is whether the insurance company will have sufficient solvency and liquidity to meet its obligations towards the insured party.

One of the numerous objectives of the financial managers is to maximize the assets of the shareholders. The maximization of shareholders' assets depends on several factors such as managing the lower cost of capital, reducing the debt, etc. All these issues are managed by reaching the optimal capital structure. As a result, the financial managers strive to ensure an optimal mixture of debt and equity in the company's capital structure.

Is there an optimal capital structure in reality, or not? What are the potential factors that affect such optimal capital structure? Even though the foregoing questions are of great significance, the academic theories have not provided satisfactory answers to such practical questions.

On the contrary, the capital structure theories still remain one of the most debatable issues in the field of modern finance. In other words, currently there isn't any acceptable capital structure. In spite of decades of intensive research, 
the theories and all existing assumptions contradict each other. Some research was conducted from the perspective of developed economies. Therefore, it is difficult to acknowledge whether the conclusions of theoretical and empirical research conducted in developed economies, are also applicable in developing economies.

In the research of Rajan and Zingales (1995):" What do we know about capital structure?,Some facts from international data", authors have investigated whether the alternative of capital structure in other countries is based on factors that are similar to those that affect the capital structure of American companies. The research was conducted in various companies of USA, comparing it with the structure of companies of G7 countries. The analysis shows that in general the factors associated with the debt (leverage) are the same among these countries and USA, but that does not mean that these factors determine the capital structure. For example, the leverage increases in all countries with the exception of Germany.

Their conclusions suggest that there were some common attributes in the capital structures of companies in various countries, but they stress the necessity for further research to be conducted in order to identify the determinants of the capital structure in particular institutional environments or in particular countries.

The optimal capital structure is closely related to the accomplishment of company goals. The insurance companies are particularly interested in determining the capital structure because these companies seek funds in order to settle the claims or compensate the damages at the time of their occurrence. Just as in other developing economies, the field of capital structure in our country has not been researched yet. Therefore, this study aims to identify the potential determinants of the capital structure among insurance companies in our country.

\section{Theoretical Framework}

The capital structure theories are among the most interesting theories in the field of finance. These theories provide explanations to the questions as to whether companies should get loans, as to how the companies should choose their capital structure, etc. There is yet no formula available about the ratio between the debt and equity; however, the empirical studies show that profitability, assets, taxes, differences between industries, uncertainty of operative revenues, etc., should be taken into account when decisions for capital structure are made.. The real debate on the capital structure began after the publication of the theorem of Modiglian and Miller (MM) in 1958. With an assumption of perfect and taxfree market, MM suggested that the selection of the debt-to-equity ratio was independent from the company's value. Their second proposition provides that determining company's leverages does not have an effect on the weighted average cost of capital. The third proposal was that the market value is independent from the dividend policies of a company. The fourth proposal provides that the equity holders-share holders are indifferent to the company's financial policy. (Kopecky,Sugrue,Tucker, 2011).

Even though theoretically their proposition sounds good, it is valuable only when the market conditions are perfect (absence of taxes being one of them), which in fact are impossible in the real world. They corrected this proposition in 1963, by including the effect of taxes on the company's value and cost of equity (Modigliani and Miller, 1963). According to trade-off model, the optimal capital structure does not exist. A company determines the level of its aimed debt and then gradually moves in its direction. According to this theory, the use of leverage in a company is dependent on three factors: (i) taxes, (ii) bankruptcy costs, and (iii) agency costs. Both models, the one based on taxes and the one based on agency costs, are supported by Kraus and Litzenberger (1973), Jensen and Meckling (1976), Miller (1977), Kim (1978), Grosman and Hart (1982) etc.

The Agency Theory studied by Jensen and Meckling in 1976, also suggests a level of optimal debt in capital structure by minimizing the agency costs arising from divergent interests of managers and debt holders. On the other hand, the hypothesis proposed by Myers and Majluf (1984) predicts that the information symmetry between managers and investors creates a preference over sources of financing. Starting from the internal funds, followed by debt, and then equity, the companies operate in this manner in order to finance the investments thus striving to minimize the costs in the selection of their sources.

In a research related to the companies listed in the Nepal stock exchange, were analyzed the determinants of capital structure, such as: size of company, business risk, growth of company, payment of dividends, etc. The multiple regression modelwas used to assess the impact of explaining variables on capital structures of companies. In the previous analysis the commercial banks and insurance companies were included. This study shows that the size, growth rate and profit rate are statistically important determinants of capital structure of the listed companies (Keshar. \& Baral, 2004).

In another research on 106 companies listed in the Swiss stock exchange for the period 1991-2000, it was 
concluded that the company size, the tangible assets and business risk are positively related to the debt ratio, whereas the company growth and profit are negatively related to the debt (Philippe, et al, 2003).

The study on life insurance companies in Pakistan investigated the impact of company's characteristics on the equity of life insurance companies. For this reason, the debt ratio was taken as a dependant variable whereas company's profitability, size, growth, life, risk, tangible assets and liquidity ratio were taken as independent variables. The result of OLS regression model shows that the size, profitability, risk, liquidity ratio and life are important determinants of capital structure of life insurance companies. (Ahmed, et al 2010).

\subsection{Determining factors of capital structure among insurance companies}

This segment sheds light on the aspects that are considered very important in deciding on the capital structure of insurance companies. Sharif, Naeem and Khan in their research: " Characteristics of companies and capital structure: An analysis of data for insurance sector in Pakistan" determined that profitability, life and income have a converse relationship with debt and that they are important. Liquidity also has converse relationship with the debt ratio, but that is not of a great importance. Otherwise, the size and growth of a company have direct impact on debt but only the size is important. These results are compatible with theories such as pecking and trade off theory (Sharif,Naeem and Khan, 2012). In a study: "Optimal capital structure of insurance companies" from Laeven and Perotti, authors aimed to research the payment ability of insurance companies located in Holland, for years 2005-2009, particularly in the years during which the financial crises deepened. The study conclusion was that during the years 2007 and 2008, the payment ability of companies during these years fell significantly. The financial crisis prompted the insurance industry (as well as other financial intermediaries) to review the architecture of their capital (Laeven \& Perotti, 2010). Gründl and Schmeiser in their study: "Risk-Performance measurement and capital allocation in insurance companies", conclude that usually the physical assets of a company also play a small role in insurance associations. This is of a special importance, because the customers (often) are at the same time debt holders of an insurance company (Gründl and Schmeisr, 2002). Another research on insurance companies was conducted in Jordan with the title: "Determinants of capital structure: A case study of industrial companies of Jordan". The research was conducted in all industrial companies listed in the stock exchange of this country, for the period 2004-2007, during which the factors of capital structure of these companies were examined (Shubir, 2010). Some of the studies applied various leverage ratios in order to represent the capital structure of a company. The differences are obvious in terms of both, one in the selection of numerator and the other in selection of a denominator of debt ratio. Some researchers used only long-term debt (Chkir and Cosset, 2001), whereas others selected total debt as numerator (Bevan and Danbolt, 2002). Some of them used the company's market value as a common denominator (Chkir and Cosset, 2001), whereas others used company's accounting value (Graham and Harvey, 2001; Mazur, 2007). In our research, we used total debt ratio for total assets.

Many studies showed that the decision related to capital structure is affected by the company's growth rate, profitability, company size, company life, liquidity ratio, tangible assets, etc.

\section{Research methodology}

This research was conducted in order to determine the factors that may affect the decisions on capital structure of insurance sector in Kosovo. The data used-financial statements were retrieved from the website of Central Bank of Kosovo for a period of three years (2009-2012) for ten general insurance companies and one life insurance company that operates in the insurance market in Kosovo. They are: KS. "Illyria Life", KS. "Grawe Elsig", KS. "Sigkos" KS." Croatia Sigurimi", KS. " Sigma" KS. Sigal Uniqa Group, KS. "Insig", KS."Siguria", KS."Kosova e re", KS. "Illyria", KS. "Dardania" (http://www.bqk-kos.org).

\subsection{Summary of hypothesis and definition of variables}

Below we will discuss these variables and their relationship to capital structure. Life of company: Age or life of company is a standard measure of capital structure that is used in many studies. In a study related to capital structure of insurance companies the age or life of company's operation is negatively related to the debt indicators. According to the author, this happens because the longer the companies operate the more they should be able to create internal funds (Abu Sayeed, 2011).

As long as a company conducts business activities for a long time, it places itself in a continuous business and 
increases its capacity to get into debts, therefore its life is positively related to its debt (Shubiri,2010). The longer the life of a company the bigger its capacity to get loans (Usman Hassan, 2011). The preceding arguments lead us to two hypothesis of different relationships:

First hypothesis:

Ho: Life of company and its debt ratio have a negative relationship between them.

Hi: Life of company and its debt ratio have a positive relationship between them.

Size of company: A large number of studies show that the size of company and the capital structure decisions are correlated. Large companies that are more diversified have smaller chances for bankruptcy (Titman and Wessels, 1988). These studies showed that the size of company and leverage ratio are positively related (Bauer, 2004; Eriotis et al, 2007; Jong, Kabir R, Nguyen TT, 2008; Zou and Xiao, 2006). Based on these studies, we come up with the second hypothesis:

Ho: There is a negative relationship between the size of company and its debt ratio among insurance companies in Kosovo.

Hi: There is a positive relationship between the size of company and its debt ratio among insurance companies in Kosovo

Growth of company: Some researchers in their empirical studies provide a positive relationship between increased sales and leverages (Titman \& Wessels, 1988). There are many debates concerning the relationship between the growth rate and leverage scale. According to the hypothesis of pecking theory, a company will initially use the internally generated funds that cannot be sufficient for a growing company. The other option for growing companies is to use the debt financing which means that a growing company will have a high debt (Drobetz and Fix, 2003).

When facing with a higher debt cost, the growing companies will rely less on debt and more on equity. In accordance with this, (Titman and Wessels 1988, Barclay, Smith and Watts, 1995 and Rajan and Zingales, 1995), all findings show a negative relationship between the size of company and its debt. The growth may prompt a greater demand for internally generated funds and resort the company to loans (Hall, G.C. Hutchinson, P.J. \& Michaelas, N., 2004). The companies with the biggest growth will have relatively high debts, therefore, taking these facts into account we assume:

Third hypothesis:

Ho: Size of company has a negative relationship with its debt ratio among insurance companies in Kosovo.

Hi: Size of company has a positive relationship with its debt ratio among insurance companies in Kosovo.

Liquidity of company: Research has shown that there is a positive correlation between the company's liquidity and company's capital structure. Liquidity is the ability of company to meet its short-term obligations. The higher the liquidity of a company the better is company able to pay the debt interests. A company with high liquidity can rely on debt as a great contributor to capital structure because it can easily pay that debt (Fama and French, 2005).

A company may use liquid assets to finance its activities and investments when the external financing is not available or is expensive. On the other hand, the high liquidity will enable a company to deal with the unexpected and to withstand its obligations during the periods of low revenues (Liargovas, dhe Skandalis, 2008). In compliance with this, we state the fourth hypothesis:

Fourth hypothesis:

Ho: There is a negative relationship between liquidity and debt ratio among insurance companies.

Hi: We expect a positive relationship between liquidity and debt ratio among insurance companies.

Fixed assets turnover: A company with more fixed assets may get a loan with relatively low interest because it uses these assets as guarantee to creditors. In various studies the empirical evidence provides different conclusions about the effect of tangible assets on capital structure.

Many empirical studies have found a positive relationship between the tangible assets and the debt, (Rajan and Zingales, 1995), and (Titman and Wessels, 1988). As expected, many authors in their research conclude about the negative relationship between debt and tangible assets. A company will get a loan with low interest rate because it has a high percentage of fixed assets compared to a company whose cost of taking a loan is high because of a low percentage of fixed assets. Based on these results we state the last hypothesis:

Fifth hypothesis:

Ho: Fixed assets ratio has a negative effect on debt ratio.

Hi: Fixed assets ratio has a positive effect on debt ratio.

Table 1 presents a summary of hypotheses and the expected ratio between the independent variable and debt ratio as a dependant variable. Table 2 presents the mode of calculation of each variable and the source of these calculations. 


\subsection{Summary of hypotheses}

Dependant variable:

Debt ratio

Independent variables:

\begin{tabular}{|c|c|c|c|}
\hline Variables & $\begin{array}{l}\text { Expected relation } \\
\text { (hypotheses) }\end{array}$ & $\begin{array}{l}\text { Results of various } \\
\text { studies }\end{array}$ & Source: \\
\hline Life of company & $\begin{array}{l}\mathrm{Ho:}- \\
\mathrm{Hi}:+\end{array}$ & $+/-$ & Shubiri, 2010; Usman Hassan, 2011. \\
\hline Size of company & $\begin{array}{l}\text { Ho: - } \\
\text { Hi: }+\end{array}$ & $+1-$ & $\begin{array}{l}\text { Titman and Wessels, 1988; Aprilia, 2009; Yassin } \\
\text { Almajali 2012; etc. }\end{array}$ \\
\hline Liquidity ratio & $\begin{array}{l}\text { Ho: - } \\
\text { Hi: + }\end{array}$ & $+/-$ & Liargovas, amd Skandalis, 2008. \\
\hline Growth of company & $\begin{array}{l}\text { Ho: - } \\
\text { Hi: }+\end{array}$ & - & Rajan and Zingales, 1995. \\
\hline Fixed assets & $\begin{array}{l}\mathrm{Ho:}- \\
\mathrm{Hi}:+\end{array}$ & $+/-$ & Titman and Wessels, 1988. \\
\hline
\end{tabular}

\section{Source:}

Usman Hassan, 2011; Sharif, Adnan Naeem and Khan, 2011; Fama and French, 2005; etc.

\subsection{Analytical techniques}

\begin{tabular}{|c|c|c|c|}
\hline Variable & Definition & Measurement ( formula): & Reference: \\
\hline RB & Debt ratio & Total debt / Total assets & $\begin{array}{l}\text { Usman Hassan, 2011; Sharif, Adnan Naeem and } \\
\text { Khan, 2011; etc. }\end{array}$ \\
\hline AG & Life of company (age) & $\begin{array}{l}\text { (Year of observation - year the company was } \\
\text { established) }\end{array}$ & Abu Sayeed, 2011. etc. \\
\hline CS & Size of company & $\begin{array}{l}\text { Natural logarithm for total assets of each } \\
\text { company }\end{array}$ & Aprilia, 2009; Yassin Almajali 2012; etc. \\
\hline RL & Liquidity of company & Short-term assets/Short-term liabilities & $\begin{array}{l}\text { Gashaw Ayele, 2012; } \\
\text { Usman Hassan, } 2011 .\end{array}$ \\
\hline GR & Growth of company & Growth of assets from year to year & Gashaw Ayele, 2012. \\
\hline TA & Fixed assets & Fixed assets /Total assets & Suck Song, 2009; etc. \\
\hline
\end{tabular}

\subsection{Model specification}

The model was developed in a manner that explains the impact of abovementioned factors on capital structure of insurance companies in Kosovo. For this purpose, the debt ratio was taken as a dependant variable whereas life of company, size of company, liquidity ratio, growth rate, fixed assets ratio as independent variables, wherein:

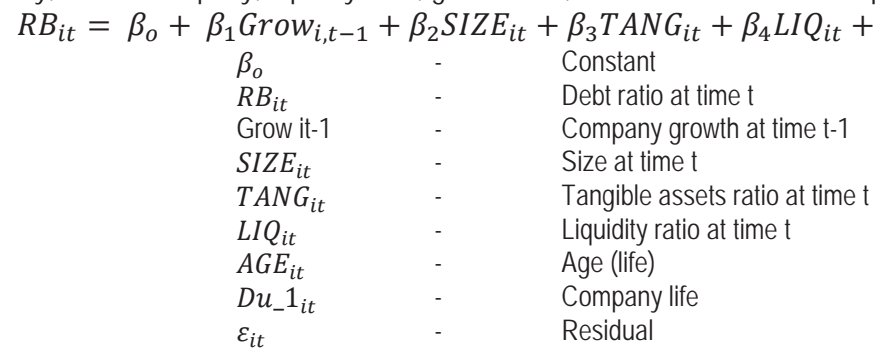

It should be clarified that under the group of insurance companies, besides the general insurance companies, we have included one life insurance company which operated in Kosovo market. Therefore, in order to control a potential effect that this company could reflect on the final result, a dummy variable was included in a regression as well (du_1). The variable takes value 1 when company exclusively provides life insurance services and 0 when general services are provided. 


\subsection{Analysis and discussion of results}

Model 42: Random-effects (GLS), using 33 observations

Included 11 cross-sectional units

Time-series length $=3$

Dependent variable: RB LEV

\begin{tabular}{|c|c|c|c|c|c|}
\hline & Coefficient & Std. Error & t-ratio & $p$-value & \\
\hline Const & -0.0103789 & 0.112053 & -0.0926 & 0.92691 & \\
\hline CS & 0.0177794 & 0.00579992 & 3.0655 & 0.00502 & $\star \star \star *$ \\
\hline$A G$ & 0.0445187 & 0.00678499 & 6.5613 & $<0.00001$ & $\star \star \star *$ \\
\hline GR 1 & 0.0981298 & 0.0447879 & 2.1910 & 0.03761 & ** \\
\hline $\mathrm{RL}$ & 0.0127911 & 0.0227262 & 0.5628 & 0.57837 & \\
\hline TA_1 & 0.387609 & 0.175258 & 2.2116 & 0.03599 & ** \\
\hline du_1 & -0.856366 & 0.173241 & -4.9432 & 0.00004 & $\star \star *$ \\
\hline
\end{tabular}

* Significant in level $1 \%$

** Significant in level 5\%

*** Significant in level $10 \%$

\begin{tabular}{llll}
\hline Mean dependent var & 0.600257 & S.D. dependent var & 0.199562 \\
Sum squared resid & 0.144295 & S.E. of regression & 0.073104 \\
Log-likelihood & 42.80971 & Akaike criterion & -71.61941 \\
Schwarz criterion & -61.14386 & Hannan-Quinn & -68.09471 \\
\hline
\end{tabular}

Breusch-Pagan test -

Null hypothesis: Variance of the unit-specific error $=0$

Asymptotic test statistic: Chi-square $(1)=4.19952$

with $p$-value $=0.0404355$

Hausman test -

Null hypothesis: GLS estimates are consistent

Asymptotic test statistic: Chi-square $(5)=5.65056$

with $p$-value $=0.341719$

The model explained above is believed to be suitable and appropriate for this analysis since the test results (Breusch Pagan and Hausman) confirm this. While Breusch Pagan test prefers RE model to pooled OLS, Hausman confirms its accuracy in comparison with FE model. Therefore, the analysis of this research concludes that RE model is the most suitable one.

Furthermore, the regression result shows that life insurance company has special effects, thus use of dummy variable is confirmed to be appropriate since it is also statistically significant. The negative coefficient shows that the life insurance companies are less inclined to support their activity in debt compared with companies that provide general insurance services.

Table 3.4. shows that the size coefficient is positive and statistically significant at the level of $10 \%$. This predicts that the large insurance companies in Kosovo prefer debt more when creating capital structure. The results show a positive relationship between leverages and size of life insurance sector for the period analyzed, which confirms our hypothesis.

The positive coefficient of liquidity ratio shows a positive relationship between liquidity ratio and debt ratio. However, it was found that this positive relationship is statistically insignificant with p-value of 0.578 .

Even it is a positive sign, it confirms that the companies with high liquidity are expected to have a higher debt ratio, but the insignificant results shows that the liquidity ratio was not considered an appropriate explaining variable of debt ratio in insurance sector.

A positive relation between the life of company and debt ratio is observed on the basis of the research conducted by Diamond (1894), who concludes that a company has built a good reputation through years; its name is well known in market, which monitored the capability of company to fulfill its obligations at the appropriate time. Table 3.4. shows that the coefficient of life is positive and statistically significant at the level of $10 \%$, which confirms our hypothesis.

The table also shows that the value of tangible assets coefficient is positive and that the $p$ value is 0.356 . The tangible assets ratio is statistically significant when explaining the debt ratio. The positive relationship shows that a company with high percentage of fixed assets can easily increase its debt or get a loan with relatively low interest rate. 
The result also shows that the growth coefficient is positively related with debt ratio thus being significant as well. Companies that have greater opportunity to grow and to generate more income in the future, should utilize debt more as they will be in a better position to pay the interest.

\section{Conclusion}

Five explaining variables were used to measure their effect on debt ratio and four of them were found to be statistically significant when measuring the impact of companies' debt ratio on insurance industry in Kosovo. Nevertheless, in line with the findings and conclusions of this research, what remains to be done is that company management of insurance industry in Kosovo should take into consideration the results from this research in order that these companies set up a more favorable financing structure.

Based on the research results, the insurance companies should have a high consideration for asset increase because the size of company is an important factor that has a positive effect on debt/equity ratio.

This study may open horizons for future studies and it could be interesting to focus on the following aspects:

- To consider the difference between long-term debt and short-term debt,

- To extend the data to other countries and macroeconomic factors should be included as independent variables.

\section{References}

Aprilia, Rini, 2012. The Joint Determination of Leverage and Maturity: Empirical Evidence from Malaysia. Forum Bisnis Dan Kewirausahaan; Jurnal IImiah STIE MD.P Vol. 2 No.1 faqe 13, 14. Stockholm.

Abate, Gashaw, 2012. Factors Affecting Profitability of Insurance Companies in Ethiopia: Panel Evidence. Addis Ababa University Libraries Electronic Thesis and Dissertations: AAU-ETD! faqe, 12- 14.

Barclay, M.J., Smith C.W. and Watts, R.L., 1995. The determinants of corporate leverage and dividend policies. Journal of Applied Corporate Finance. Vol. 7 faqe 4-19.

Bauer P., 2004. Determinants of capital structure: Empricial evidence from Czech Republic. Czech Journal Economics Finance. 54(1-2): $2-21$.

Bevan, A A, \& Danbolt, J., 2002. Capital structure and its determinants in the UK - a decompositional analysis. Applied Financial analysis. Vol. 12, no. 3, faqe 159-170.

Chkir, IE. \& Cosset, JC., 2001. Diversification strategy and capital structure of multinational corporations. Journal of Multinational Financial Management. Vol. 11, no. 1, faqe 17-37.

Diamond, D.W., 1984. Financial Intermediation and Delegated Monitoring. Review of Economic Studies, 51, 447-663.

Drobetz, W. and Fix R., 2003. What are the determinants of the capital structure? Some evidence for Switzerland. University of Basel, WWZ/ Department of Finance. Working Paper No. 4/03.

Eriotis N, Vasiliou D, Ventoura-Neokosmidi Z., 2007. How firm characteristics affect capital structure: an empirical study. Manager. Financ., 33(5): 321-331.

Fama EF, French KR., 2002. Testing trade-off and pecking order predictions about dividends and debt. T. Rev. Financ. Stud., 15(1): 133.

Graham, JR, \& Harvey, CR., 2001. The theory and practice of corporate finance: evidence from the field. Journal of Financial Economics. Vol. 60, no. 2-3, pp. 187-243.

Hall GC, Hutchinson PJ, Michael N., 2004. Determinants of the capital structures of European SMEs. J. Bus. Financ. Account. 31(5/6), $711-728$.

Jensen, Michael C., 1976. Theory of the Firm: Managerial Behavior, Agency Costs and Ownership Structure; Harvard University Press.

Jong AD, Kabir R, Nguyen TT., 2008. Capital structure around the world: the roles of of firm- and country-specific determinants. J. Bank Financ. 32: 1954-1969.

Kopecky, Kenneth J., Sugrue ,Timothy F., Tucker , Alan L., 2011. M\&M 1963: An Alternative Equilibrium. Social science research network.

Kraus \& Litzenberger, 1973. A State-Preference Model Of Optimal Financial Leverage. The Journal of Finance. Volume 28, Issue 4, pages 911-922.

Mazur, K., 2007. The determinants of capital structure choice: Evidence from Polish companies. Int. Advanced Econ Res. Vol. 2007, faqe 495-514.

Liargovas, P. \& Skandalis, K., 2008. Factor affecting firms financial performance: The Case of Greece. University of Peloponnese.

Modigliani, F. and Miller, M.H., 1958. The Cost of Capital, Corporate Finance, and the Theory of Investment. American Economic Review. Vol. 48, 261-297.

Rajan R.G. and Zingales L., 1995. What do we know about Capital Structure? Some evidence from international data. The Journal of Finance. Vol. 50 (5), 1421-1460.

Sayeed, Mohammad Abu, 2011. The Determinants Of Capital Structure For Selected Bangladeshi Listed. International Review of 
Business Research Papers. Vol. 7. No. 2 Pp. 21-36;

Sharif, Bilal, Naeem, Muhammad Adnan and Khan, Abdul Jabbar 2011. Firm's characteristics and capital structure: A panel data analysis of Pakistan's insurance sector. Hailey College of Commerce, University of the Punjab. Lahore, Pakistan. Accepted 28 November, 2011.

Sheridan, Titman. Roberto, Wessels., 1988. The Determinants of Capital Structure Choice. The Journal of Finance. Vol. 43(1) pp 1-19.

Suck Song ,Hun, 2004: Capital Structure Determinants An Empirical Study of Swedish Companies. Stocholm 2004. Paper to be presented at conference, "Innovation Entrepreneurship and Growth"

Titman S. and Wessels R., 1988. The determinants of Capital Structure Choice. The Journal of Finance. Vol. 43 (1), 1-19.

Titman, S., 1984. The effect of capital structure on the firm's liquidation decision. Journal of Financial Economics. Vol. 13, pp. 137-151.

Usman Hassan, Shehu 2012. Determinants of Capital Structure In the Nigerian Listed Insurance Firms. International Journal of Advanced Research in Management and Social Sciences. Vol. 1 No. 2.

Wiwattanakantang, Y., 1999. An empirical study on the determinants of capital structure of Thai firm. Pacific-Basin Finance J. Vol. 7 , 371-403.

Zou H, Xiao JZ., 2006. The financing behavior of listed Chinese firms. T. Br. Account. Rev. 38, 239-258.

http://shs-ks.com/

http://www.crosig.hr/

http://www.illyriainsurance.com/

http://www.graweelsig.com/index.htm

http://www.dardaniainsurance.com/

http://www.kosovaere.com/

http://www.sigal.com.al/

http://www.sigkos.com/

http://www.sigma-ks.net/

http://www.ks-siguria.com/ks-siguria/

http://www.bqk-kos.org/?cid=1,43

\section{Appendix}

\begin{tabular}{ccccc}
\hline Variable & Mean & Median & Minimum & Maximum \\
RB_LEV_ & 0.575197 & 0.609738 & 0.0434396 & 0.930075 \\
RL & 1.14559 & 0.851310 & 0.125767 & 3.72138 \\
CS & 13.6442 & 15.6353 & 9.08727 & 16.8877 \\
AG & 7.13636 & 8.00000 & 1.00000 & 12.0000 \\
GR & 0.142634 & 0.117910 & -0.479479 & 0.906199 \\
TA & 0.169560 & 0.0708625 & 0.0009651 & 0.996860 \\
\hline Variable & Std. Dev. & C.V. & Skewness & Ex. kurtosis \\
RB_LEV_ & 0.212318 & 0.369122 & & -0.259745 \\
RL & 0.971243 & 0.847809 & 1.32873 & 0.683151 \\
CS & 3.27325 & 0.239900 & -0.564364 & -1.57830 \\
AG & 2.96170 & 0.415015 & -0.476680 & -0.680701 \\
GR & 0.229431 & 1.60853 & 0.869715 & 2.86268 \\
TA & 0.240962 & 1.42110 & 2.41599 & 5.49849 \\
\hline Variable & $5 \%$ Perc. & $95 \%$ Perc. & $1 \mathrm{Q}$ range & Missing obs. \\
RB_LEV_ & 0.138923 & 0.901349 & 0.319730 & 0 \\
RL & 0.159876 & 3.40585 & 0.917487 & 0 \\
CS & 9.09522 & 16.6242 & 7.05318 & 0 \\
AG & 1.25000 & 11.7500 & 4.00000 & 0 \\
GR & -0.180180 & 0.668783 & 0.185290 & 0 \\
TA & 0.002612 & 0.967503 & 0.234696 & 0 \\
\hline
\end{tabular}

